\title{
STAROŻYTNOŚCI ZAGRANICZNE NA ŁAMACH „TYGODNIKA ILUSTROWANEGO” DO 1914 ROKU
}

SŁowa KLUCzowe: „Tygodnik Ilustrowany”; historia archeologii; starożytności; XIX wiek

KEYwORDS: „Tygodnik Ilustrowany”; history of archeology; antiquities; 19th century

[...] w ostatnich latach laury Schliemanna pobudziły niejednego uczonego do oszukiwań archeologicznych. Zdobycze, na gruncie dawnej Troi poczynione, bogate żniwo, zebrane przez starożytników na polach pogrzebanej pod zwaliskami Olympii, zwróciły uwagę poświęconych i niepoświęconych na dziedziny, w których kwitnęła swojego czasu cywilizacya helleńska. Jedni szukali złotych dyademów, naszyjników królewskich i innych kosztowności, wiedzeni chęcią zwykłego zysku, inni zaś, pałając szczerą ku nauce miłością, pilnie zaglądać poczęli w łono ziemi, żeby z niej bez względu na wartość materialną wykopalisk, wydobywać najaw pogrzebane pomniki dawnego życia, ślady ubiegłych stuleci, zabytki dziejów dotychczas pokryte nieprzejrzystą zasłoną tajemnicy (Pawiński 1880: 386).

\section{WSTĘP}

Starożytni Grecy zwykli mawiać, że piękno tkwi w sztuce, jednak zaraz dodawali, że najpiękniejsza jest i tak żywa natura (Michałowski 1970: 7). Potrafili oni w doskonały sposób odwzorowywać rzeczywistość. Do dziś twórczość antycznych artystów wprawia w podziw i zachwyt. W „Tygodniku Ilustrowanym”, warszawskim czasopiśmie społeczno-kulturalnym, ukazującym się w latach 1859-1939, również odnotowywane były doniesienia o odkryciach archeologicznych. Pisano nie tylko o tym co znajdowano na ziemiach przedrozbiorowej Rzeczpospolitej, ale odnoszona się do tego co się działo poza jej dawnymi granicami. Najwięcej doniesień dotyczyło Grecji, Rzymu i Egiptu i na nich skupię się w artykule. Zakres chronologiczny tekstu obejmuje lata 1859-1914, czyli okres od ukazania się pierwszego numeru pisma do wybuchu I wojny światowej. 


\section{GrecJA}

Pierwsze artykuły jakie pojawiły się na łamach warszawskiego periodyku dotyczące antycznej Grecji to fragmenty książki Józefa Kremera (1806-1875) Grecyja starożytna i jej ogólne usposobienie i jej sztuka, która powstała na podstawie wykładów wygłoszonych przez autora w Szkole Sztuk Pięknych w Krakowie. Artykuły dotyczyły zabytków znajdującym się na Akropolu oraz życiu i twórczości Fidiasza (Kremer 1866: 167-169, 194-196).

Dwa lata później w „Tygodniku” umieszczono recenzję kolejnej książki J. Kremera Grecya starożytna $i$ jej sztuka, a zwłaszcza rzeźba, pióra Kazimierza Kaszewskiego. Streścił on główne tezy zawarte w publikacji architekta, zwracając uwagę na pewne niedopowiedzenia, brak wstępu oraz odsyłacze stosowane przez autora pracy (do jego pamiętnika Podróż do Włoch). Za minus pracy uznał również brak ilustracji. Mimo to książkę określił jako wielce pożyteczną (Kaszewski 1868: 284-285, 294).

Kremer był człowiekiem wszechstronnie wykształconym. Wiedzę teoretyczną wyniesioną z wielu znanych europejskich uniwersytetów uzupełniał licznym podróżami. Antyczne zabytki widziane z bliska wywarły na nim ogromne wrażenie. Efektem jego fascynacji były nie tylko liczne artykuły, ale i książki.

W 1870 r. starożytnej i chrześcijańskiej sztuce greckiej, poświęcony został czteroczęściowy artykuł, który powstał na bazie odczytów doktora Zygmunta Węclewskiego (1824-1887), filologa klasycznego, profesora Szkoły Głównej w Warszawie (Węclewski 1870: 179-180, 188-190, 213-215, 224-226).

Należy odnotować, że pierwsze artykuły, które ukazały się na łamach „Tygodnika” odnosiły się głównie do sztuki antycznej Grecji, ale z czasem zaczęły pojawiać się informacje o odkryciach archeologicznych. Pierwsza wzmianka o wykopaliskach pochodzi z 1867 r. i opisuje znaleziska z wyspy Therasi, należącej do archipelagu Santorini. Badacze pomimo wielu zabytków nie potrafili odpowiedzieć na pytanie jaki lud zamieszkiwał wyspę. Oczekiwano, że dalsze badania pomogą uzyskać odpowiedź na to pytanie (H. N. 1867: 7-8).

Wiele spektakularnych odkryć w XIX w. dokonał Henryk Schliemann (18221890). Dla miłośników archeologii stał się on ucieleśnieniem romantycznej idei poszukiwacza skarbów zaginionych cywilizacji. Informacje o jego dokonaniach, jak i samym odkrywcy, był publikowane również na łamach „Tygodnika Ilustrowanego" (po śmierci zamieszczono również jego biogram). H. Schliemann przez czterdzieści lat trudnił się kupiectwem. W Rosji dorobił się majątku, 
po czym zarzucił handel i od 1868 r. zajmował się wyłącznie badaniami archeologicznymi i filologicznymi (Schliemann ... 1891: 12).

W numerze 77 z 1877 r. zamieszczono informację na temat odczytu wygłoszonego przez niemieckiego pasjonata, opisującego jego badania w Mykenach. Referat został wygłoszony specjalnie dla Paryskiej Akademii Nauk. Z jego treści dowiadujemy się, że w 1876 r. Schliemann rozpoczął wykopaliska. Głównym ich celem było odnalezienie królewskich grobów i skarbca Atrydów nazywanego Grobem Agamemnona. W takcie wykopalisk odnalazł on kilka grobowców nakrytych kamiennymi płytami. Obok szczątków zmarłych znajdowało się wiele drogocennych ozdób i naczyń. Wszystkie odnalezione przedmioty przekazano do Muzeum w Atenach (W. Ch.1877: 373-374).

Wystapienie Schliemanna nie zrobiło wrażenia na autorze artykułu, który miał okazję w nim uczestniczyć. Ponadto wyraził on życzenie, aby jak najszybciej znalazła się osoba, która się zajmie w sposób profesjonalny tak ważnym znaleziskiem (W. Ch. 1877: 374). Warto podkreślić, że w odróżnieniu od innych rodzimych czasopism, w „Tygodniku Ilustrowanym” zamieszczono artykuły nieprzychylne Schliemannowi (Drzewicz 2006: 152-154; Press 1996: 521-530).

Od lat 80. XIX w. na łamach warszawskiego periodyku donoszono o zmianach jakie zaszły w Grecji w podejściu do rodzimych zabytków. Postanowiono o nie samodzielnie zadbać. Jak donosił Mścisław Edgar Trepka (1839-1919) (Toporczyk), doktor filozofii, Towarzystwo Archeologiczne Ateńskie uzyskało od władz przywilej prowadzenia badań i obowiązek czuwania nad przestrzeganiem zapisu o zakazie wywożenia poza granice państwa zabytków. M. E. Trepka zauważył jednakże, że sami nie podejmowali oni żadnych badań (nie mieli ku temu odpowiednich kwalifikacji ani środków finansowych). Postawa greckich uczonych i władz spowodowała, że niemieccy uczeni odjechali, a po ich wyjeździe nikt nie zajął się niszczejącymi zabytkami na Akropolu czy Delos. Podobny los zwiastował autor francuskim badaczom prowadzącym w Atenach Szkołę Sztuki, zwłaszcza, że jeden z tamtejszych uczonych, który prowadził wykopaliska na Delos, został aresztowany, jak mniemał Trepka, pod niesłusznym zarzutem wywiezienia do swej ojczyzny posagu. Po tym incydencie wyjechali oni z wyspy. Najprawdopodobniej archeolodzy mieli również opuścić stanowisko w Delfach (Toporczyk 1883a: 331).

Szerokim echem w Europie odbiły się badania w Olimpii. Rezultaty prowadzonych prac archeologicznych dla „Tygodnika” opisał Adolf Pawiński (18401896), jego współpracownik, a z wykształcenia historyk-archiwista związany z Cesarskim Uniwersytetem Warszawskim. Nim jednak przeszedł do odkryć 
krótko zarysował charakter samych igrzysk, które się odbywały w Olimpii. Następnie omówił historię poszukiwań zaginionego miasta, które podjęto już w XVII w. W 1829 r. odsłonięto kolumny i kilka posagów. Misję jednak przerwano w związku z niepokojami politycznymi. Na początku 2. poł. XIX w. Olimpią zainteresował się Ernst Curitius (1814-1896), niemiecki archeolog, autor Dziejów Grecji (Gran-Aymerich 2007: 730), któremu udało się nakłonić własny rząd do sfinansowania badań. Zawarto również umowę pomiędzy niemieckimi i greckimi władzami na mocy, której wszystko to co wykopano miało postać w Grecji, natomiast Niemcy otrzymali wyłączność na kopiowanie odkrytych zabytków. Z odlewów stworzono zbiór sztuki greckiej w Muzeum Berlińskim. Do końca 1881 r., jak podaje A. Pawiński, odkryto: 130 posagów i płaskorzeźb marmurowych, 6000 monet, ponad 13000 brązów i 1000 przedmiotów z terakoty. Dodatkowo 400 napisów i około 600 fragmentów z inskrypcjami (Pawiński 1885: 101-102, 117, 144).

\section{WŁOCHY}

Wiele doniesień na temat odkryć zabytków antycznych pochodziło z Włoch. $\mathrm{Na}$ żywo oglądał je w stolicy dawnego Imperium Romanum zajmujący się prawem Hieronim Wielowiejski. Wszystkie antyczne monumenty starał się opisywać w relacjach nadsyłanych do „Tygodnika”, choć faktycznie skupił się na przekazaniu własnych odczuć, co było charakterystyczne dla XIX-wiecznych opisów, w których na pierwszym miejscu znajdował się peregrynat, a na dalszy plan schodzily relacje o zwiedzanych zabytkach (Rekowska 1995: 78). H. Wielowiejskiego zachwyciły rzeźby wielkich wodzów, polityków i bóstw. Mógł on podziwiał łuk Tytusa. Odwiedził muzeum na Kapitolu. Stan zabytków Wiecznego Miasta nie przedstawiał się jednak najlepiej, co podkreślił Wielowiejski (Wielowiejski 1871: 28-29).

Inny korespondent „Tygodnika” donosił, że mają być podjęte prace nad uporządkowaniem wszystkich pomników Rzymie, które były rujnowane przez odziaływanie czynników środowiskowych i człowieka (Stecki 1871: 8).

W 1881 r. w „Tygodniku Ilustrowanym” zamieszczono artykuł Gastona Boissiera (1823-1908), filologa klasycznego, historyka i miłośnika starożytności związanego z Akademią Francuską (Gran-Aymerich 2007: 612), w którym podobnie jak Wielowiejski, opisał swoje wędrówki archeologiczne po Rzymie i Pompejach. G. Boissier zwrócił uwagę na to jak traktowano zabytki akcentując fakt, że już czasów Odrodzenia poszukiwano wszystkiego czym dałby się 
przyozdobić zamek lub pałac. W trakcie tych rabunkowych działań zniszczono wiele zabytków. W końcu jednak podjęto starania, żeby ratować zabytki. W dniu 8 listopada 1870 r. powołano superintendenta Pietro Rosę (1810-1891), archeologa, architekta i geodetę (http), natomiast dotychczasową komisję, która miała dbać o monumenty, rozwiązano (Boissier 1881: 268).

Jak donoszono w „Tygodniku Ilustrowanym”, od Koloseum rozpoczęto prace restauracyjne. W pierwszej kolejności usunięto rośliny, po których jak drwiąco pisze autor, płakać mieli Anglicy i sentymentalni poeci. Również arkady oczyszczono z gruzów. Prace, które zaplanował nowy konserwator miały objąć całą południowo-zachodnią część Rzymu, począwszy od Kapitolu do Via Appia i od Term Dioklecjana do Via Ostia. Wiosną 1872 r. planowano odrestaurować Circus Maximus i wszystkie inne zabytki, które znalazły się w obrębie wspomnianego obszaru (Stecki 1871: 8-9).

Autor artykułu Tadeusz Jerzy Stecki (1838-1888), był ziemianinem, publicysta, badaczem dziejów Wołynia (opublikował pracę Wotyń pod względem statystyczny, historycznym i archeologicznym). Przez pewien czas podróżował po Europie. Przebywał również we Włoszech. Z Florencji przesyłał informacje o bieżących wydarzeniach (Ormian-Michta 2004-2005: 95-96).

Inni korespondenci w kolejnych latach informowali o postępach prac renowacyjnych, konserwatorskich, wykopaliskowych, a także najnowszych odkryciach, które napływały do redakcji „Tygodnika Ilustrowanego" nawet pomimo faktu, że działania na rzecz renowacji miasta od $1881 \mathrm{r}$. odbywały się z mniejszym rozmachem (Kraszewski 1875: 344; Boissier 1881: 254, 276; Toporczyk 1883b: 67; Toporczyk 1886a: 90).

Na początku XX stulecia możemy jeszcze w warszawskim periodyku odnaleźć krótkie notatki o bieżących odkryciach na Kapitolu. W 1902 r. poinformowano czytelników warszawskiego periodyku o wykopaniu grobu z VIII w. p.n.e. (Kronika...1901: 864; Kronika ... 1902a: 479).

$\mathrm{Na}$ uwagę zasługuje również pomysł jednego z włoskich profesorów, który chciał przeszukać łożysko Tybru. Według jego ustaleń w rzece powinny znajdować się kosztowności, które składano bóstwu, żyjącemu w głębi wód. Spodziewał się on odkryć również broń i uzbrojenie żołnierzy. Swoje domysły uzasadniał tym, że w czasie budowy mostów lub prac przy umacnianiu wybrzeży zawsze odkrywano cenne skarby (Kronika... 1902: 940).

Wielką popularnością w XIX w. cieszyły się Pompeje. Życie miasta zostało gwałtownie przerwane 25 sierpnia 79 r. w wyniku wybuchu Wezuwiusza. Już od XV stulecia się na terenie antycznego miasta dochodziło do przypadkowych odkryć, jednak nikt nie uznawał ich za ślady Pompejów. (Beard 2010: 
9; Krawczyk 2011) Ruiny miasta zostały zidentyfikowane dopiero w 1748 r., jednakże naukowe badania podjęto w 2. poł. XIX w., jak opisywał Pawiński, ich metodyka polegała na odkopywaniu dużych powierzchni w kształcie odosobnionej wyspy. Warstwy zdejmowano poziomo, sięgając niezbyt głęboko. Dodatkowo usunięta ziemia była przesiewana, aby nie przeoczyć żadnego zabytku (Pawiński 1891: 89-90).

Powłoka naniesiona przez Wezuwiusz okazała się doskonałym środkiem konserwującym, co zauważył Giuseppe Fiorelli (1823-1896), włoski archeolog, profesor Uniwersytetu w Neapolu i dyrektor tamtejszego muzeum (Fiorelli 2011). On kierował wykopaliskami w zniszczonym mieście. Dzięki właściwościom popiołu, który bardzo szczelinie zasklepił się wokół ciał to pomimo, że uległy one rozkładowi ich kontur pozostał utrwalony w masie wulkanicznej. Badacz obmyślił, że wypełni pustą przestrzeń płynnym gipsem. Jego pomysł przyniósł nadzwyczajne rezultaty (Pawiński 1891: 90; Grant 1986: 34).

Pawiński niewątpliwie zdawał sobie sprawę z doniosłości odkrycia. Pod powłoką z popiołu zostało zatrzymane życie. Wraz ze zdejmowanymi warstwami dowiadywano się coraz więcej na temat życia codziennego mieszkańców Pompei. W trakcie wykopalisk odsłonięto: naczynia kuchenne, sprzęty domowe, przyrządy chirurgiczne, przybory toaletowe itd. Zachowała się również architektura (Pawiński 1891: 91, 109-110).

W 1895 r. donoszono na łamach „Tygodnika” o odkryciu w Boscoreale, miejscowości położonej w pobliżu Pompei, skarbu składającego się ze starożytnych sreber zawiniętych $\mathrm{w}$ niemalże całkowicie rozłożoną w momencie odkryci tkaninę. Obok znaleziono szkielet. Całość liczyła 41 przedmiotów, wśród których znalazły się: łyżki, kubki, monety i bogato ornamentowane lustra. Najliczniejszą grupę zabytków stanowiły wazy. Cały skarb został wykupiony przez Edmunda Rothschilda (1845-1934), twórcę ruchu syjonistycznego, mecenasa sztuki, który co warto podkreślić, finansował badania francuskie w Egipcie, Syrii i Palestynie (A. C. 2000: 285) i przekazany na własność Muzeum w Luwrze (A. D. 1895: 327).

W „Tygodniku Ilustrowanym” pojawiła się również krótka informacja o kolejnych już odkryciach „brązów” w Tarkwini. Zabytki przekazano do miejscowego muzeum, w którym zgromadzono bardzo bogatą kolekcję starożytności etruskich (Rozmaitości... 1883: 256). Miasto i jego okolice obfitowały w tego typu znaleziska, gdyż znajdowały się tam rozległe cmentarzyska należące do ludu Etrusków (Tarquinia: 258-259), 


\section{EGIPT}

Starożytny Egipt i będące symbolem jego cywilizacji piramidy budziły zainteresowanie choć już nie zawsze podziw. Nawet widok sfinksa nie pobudzał już emocji, tym bardziej, że częściowo był przysypany piaskiem. Zagadką, dla anonimowego autora artykułu, pozostawały jedynie hieroglify (Czterdzieści...1872: 313-314).

$\mathrm{Z}$ dużo większym respektem do zniszczonych i już nie tak malowniczo wyglądających zabytków odniósł się Władysław Górski (1846-1915), skrzypek i kompozytor (Hordyński 1959-1960: 456). Jego opinię podzielał również Emil Gebhart (1839-1908), francuski pisarz, dla którego z kolei oglądane wewnątrz grobowców malowidła nie posiadały dla niego uroku. Brak im było „piękności i wyrazu” (Gebhart 1875: 272, 307-308; Górski 1882: 306).

Wszyscy trzej podróżnicy w swoich relacjach zwrócili uwagę na ten sam problem, a mianowicie dewastację monumentalnych budowli. Władysław Górski donosił, że najokazalsza z nich, piramida Cheopsa, była pusta (Górski 1882: 306). Tak samo wyglądała kwestia zabytków w Sarapeum. Uwagę zwiedzających przyciagały sarkofagi z otwartymi wiekami, lecz już puste w środku (Gebhart 1875: 307-308). Jeszcze w 1903 r. Gaston Maspero donosił o złym stanie zabytków cywilizacji egipskiej, które trzeba jak najszybciej należało poddać renowacji (Kronika ... 1903: 958).

W numerze 287 ,Tygodnika Ilustrowanego” z 1865 r. znalazło się sprawozdanie i opis z pobytu w Kairze Michała Tyszkiewicza (1828-1897). Pierwsze na co podróżnik zwrócił swą uwagę to fakt, że jeszcze niedawno w Egipcie swobodnie można było prowadzić poszukiwania, a cudzoziemcy jeśli jawnie chcieli kopać to bez trudu otrzymywali na to zgodę od wicekróla. Zmieniło się to dzięki zabiegom twórcy Muzeum w Bulak (Tyszkiewicz 1865: 112).

M. Tyszkiewicz niewątpliwie doskonale orientował się w sytuacji panującej w Egipcie. W latach 1861-1862 prowadził tam nielegalne wykopaliska. To co udało mu się kupić lub znaleźć ofiarowywał lub sprzedawał do Muzeum w Luwrze (trafiły tam 194 obiekty spośród około 800 odkopanych). Jedynie w wyjątkowych sytuacjach odsyłał zabytki do rodzinnego majątku w Łohojsku (Gąsiorowski 1948: 24; Lipska 2003: 27).

Obowiązkowym punktem każdej podróży po Egipcie było Muzeum w Bulak, gdyż w jego wnętrzu zgromadzono wiele niezwykle ciekawych zabytków. Już przed wejściem do budynku eksponowane były posagi, które ze względu na pokaźne rozmiary nie zmieściłyby się w jego wnętrzu (Vogue 1878: $159,171-172)$. 
Pomysłodawcą i twórcą Muzeum Starożytności był Francois Auguste Ferdinand Mariette (1821-1881), francuski uczony, archeolog i egiptolog, który od 1858 r. pełnił funkcję Dyrektora Generalnego Służby Starożytności w Egipcie. On odkrył na terenie nekropolii w Sakkarze Sarapeum, w których chowano święte byki Apisy (oglądał je również E. de Vouge i E. Gebhart) (Tyldesley 2005: 113-119).

Autor artykułu Eugèn de Vogüé (1848-1910) był francuskim dyplomatą, orientalista, podróżnikiem i miłośnikiem starożytności (Vogüé...), podczas swojego pobytu w Egipcie miał okazję uczestniczyć również w poszukiwaniach prowadzonych przez dyrektora Muzeum w Bulak oraz w modnym w 2. poł. XIX w. w Europie, seansie rozwijania mumii (Kaczmarek 2008: 261). Co wspomina w następujący sposób:

Po zdjęciu niezliczonego mnóstwa bandaży ukazał się nam nagi trup w powłoce żywicznej, o członkach skurczonych i wyschłych, podczas długowiecznego przebywania w grobie (Vogüé 1878: 207).

Po śmierci Mariette jego miejsce zajął Gaston Camille Charles Maspero (1846-1916), profesor egiptologii w College de France w Paryżu, założyciel Francuskiego Instytutu Archeologii Orientalnej w Kairze. G. Maspero przyszło pracować w trudnym dla archeologii okresie, gdy Egipt stanął na skraju bankructwa pod wspólnym zarządem brytyjsko-francuskim. Brytyjczycy sprawowali kontrolę na sprawami finansowymi, a Francuzi zajmowali się wymiarem sprawiedliwości i kulturą. Zgodnie z podjętymi ustaleniami dyrektorem Służby Starożytności miał być zawsze Francuz. To prowadziło do częstych konfliktów z badaczami brytyjskimi (Tyldesley 2005: 119).

W „Tygodniku Ilustrowanym” z 1886 r. znajdujemy informację, w której domniemywano, że w związku z uzyskaniem przewagi w Egipcie przez Brytyjczyków i jednoczesnym wyjazdem Maspero, dyrektora Muzeum w Bulak z Kairu, zbiory tej placówki zostaną przewiezione do Muzeum w Luwrze (Toporczyk 1886b: 213).

Bardzo głośnym wydarzeniem w dziejach badań egiptologicznych było odkrycie sarkofagu Ramzesa II, faraona z XIX dynastii. W dniu 13 czerwca 1886 r. w Muzeum Starożytności w Bulak w obecności wielu zagranicznych gości, Maspero rozwinął bandaże. Utwierdzono się wtedy w przekonaniu, że znaleziono Ramzesa II (W[incenty] K[orotyński] 1886: 213-214; Tyldesley 2002: 227).

Kolejnym spektakularnym odkryciem było odnalezienie w 1898 r. grobowca Totmesa III, przez Victora Loreta (1859-1946), francuskiego 
egiptologa i archeologa, ówczesnego dyrektora Służby Starożytności w Egipcie (Najnowsze... 1898: 415; Niwiński 2003: 378).

Obok Maspero równie ważną rolę $\mathrm{w}$ badaniach nad Egiptem odegrał Henryk Brugsch (1827-1894), niemiecki egiptolog, przyjaciel i współpracownik Mariette podczas badań w Memfis. (Brugsch 2011) W „Tygodniku Ilustrowanym" H. Brugsch pojawił się jako twórca teorii, która mówiła, że odkrycia archeologiczne potwierdzają wydarzenia opisane w Biblii. Przeciwny temu poglądowi był inny niemiecki egiptolog, August Eisenlohr (1832-1902), który podważał nawet istnienie samego Mojżesza. J. I. Kraszewski był w pełni przekonany do tez wysuniętych przez prof. Brugscha, choć zdawał sobie sprawę, że spór pozostanie długo jeszcze nierozstrzygnięty.

Czytanie egipskich pomników nie jest łatwem, podlega wielu wątpliwościom; można jednak największe pokładać zaufanie w człowieku, który pięćdziesiąt lat życia poświęcił badaniu pomników i z porównania niezmiennej ich liczby, mógł wnioski stanowcze wyciagnąć (Kraszewski 1872: 218).

W 1901 r. Albert Gayet (1856-1916), francuski egiptolog, odkrył w Antinoi (Antinopolis) mumię kobiety, na której ciele zachowały się szaty. Napis na grobowcu głosił, że spoczywała tam „Panu Thais”. Niezwykły zabytek został przewieziony do Muzeum w Guimet'a w Paryżu. Z okazji pozyskania nowego eksponatu w Muzeum odbył się odczyt A. Gayeta, w którym wyjaśnił, kim była tajemnicza Thais. Po odczycie odbył się pokaz. Obok A. Gayeta pojawiła się kobieta, ubrana w zwiewne szaty wzorowane na tych, w które była ubrana mumia. W jej rolę wcieliła się jedna $\mathrm{z}$ tancerek paryskiej opery. Wykład wraz z pokazem ,żywej mumii” wzbudził uznanie wśród wszystkich obecnych (Kronika...1902c: 97).

Egipskie zabytki trafiały nie tylko do muzeów brytyjskich i francuskich. Wiele eksponatów przewieziono również do Włoch. W Muzeum w Turynie Ernesto Schiaparelli (1856-1928), włoski egiptolog, zgromadził odkopane przez siebie przedmioty z Doliny Królów. Pochodziły one z grobowca budowniczego tebańskich gmachów Kha i jego żony Mirit. W turyńskim muzeum odtworzono wystrój wnętrza grobowca (Przed ... 1909: 321).

\section{Podsumowanie}

W pierwotnych założeniach twórców „Tygodnika Ilustrowanego" barwa pisma miała być czysto krajowa. Już w Prospekcie zakładano, że nie zabraknie $\mathrm{w}$ nim również doniesień o starożytnościach. W hierarchii podejmowa- 
nych tematów Archeologia, opisy i widoki kościolów, zamków, pomników historycznych i innych zabytków przeszłości twórcy warszawskiego czasopisma umieścili na szóstej pozycji spośród trzynastu wymienionych (Unger 1859).

Od pierwszych numerów pisma pojawiły się informacje o starożytnościach krajowych, natomiast doniesienia o starożytnościach zagranicznych zaczęły ukazywać się w 2. poł. lat 60 . XIX stulecia i od tego momentu ich liczba systematycznie rosła. Najwięcej tekstów opisujących odkrycia i zabytki antyczne przypada na lata 80 . tegoż wieku. Pojedyncze artykuły pojawiały się w latach 90. Na początku XX w. ponownie wzrosła liczba tekstów opisujących starożytności.

Zagadnienia archeologiczne nie ograniczały się jedynie do wiadomości o wykopaliskach. Na łamach „Tygodnika” umieszczano biogramy badaczy i kolekcjonerów. Informowano o wystawach i muzeach gromadzących artefakty z czasów antycznych. Opisywano także same artefakty. Pojawiały się również przedruki artykułów obcojęzycznych. Znajdowały się one w dziale Artykuly treści naukowej, z innych piśmiennictw czerpane. Drobne doniesienia o odkryciach zagranicznych były publikowane w dziale Ze świata obcego redagowanym przez M. E. Trepkę (Toporczyka), a później w Kronice powszechnej.

Autorzy artykułów reprezentowali różne dyscypliny naukowe. Zawodowo zajmowali się: historia, architektura, sztuką, filologią klasyczną. W znacznej większości mogli oni na żywo podziwiać niezwykłe zabytki Grecji, Włoch i Egiptu.

\author{
mgr Aleksandra Jeleń \\ Uniwersytet Łódzki \\ Wydział Filozoficzno-Historyczny \\ Instytut Archeologii \\ ul. Uniwersytecka 3 \\ 90-137 Łódź \\ ola_jelen@wp.pl
}




\section{BibLIOGRAFIA}

A. C. (2000), Rothschild Edmund James de, [w:] Historia i kultura Żydów polskich, red. A. Cała, H. Węgrzynek, G. Zalewska, Wydawnictwo Szkolne i Pedagogiczne, Warszawa, s. 285-287.

A. D. (1895), Skarb pompejański, „Tygodnik Ilustrowany”, nr 45, s. 327.

Beard M. (2010), Pompeje. Życie rzymskiego miasta, (tłum. N. Radomski), Dom Wydawniczy REBIS, Poznań.

Boissier G. (1881), Wędrówki archeologiczne, „Tygodnik Ilustrowany”, t. XII, nr 303, s. 253-254; nr 304, s. 268-269; nr 305, s. 275-277; nr 306, s. 300-301; nr 307, s. 307.

Czterdzieści... (1872), Czterdzieści wieków, „Tygodnik Ilustrowany”, t. X, nr 260, s. 313-314.

Drzewicz A. (2006), Polska prasa końca XIX wieku o Henryku Schliemannie $i$ wykopaliskach $w$ Troi, [w:] Troja. Sen Henryka Schliemanna, red. G. Orlińska, Państwowe Muzeum Archeologiczne, Warszawa, s. 148-161.

Gąsiorowski S. J. (1948), Badania polskie nad sztukq starożytnq. Relacje podróżników - kolekcjonerstwo, badania naukowe, PAU, Kraków.

Gebhart E. (1875), Memfis. Sztuka i bogi egipskie. Wyjątek z podróży archeologicznej, „Tygodnik Ilustrowany”, t. XVI, nr 408, s. 272; nr 409, s. 288; nr 410, s. $307-308$.

Gran-Aymerich A. (2007), Les chercheurs de passé 1798-1945, CNRS Edition, Paris.

Grant M. (1986), Miasta Wezuwiusza. Pompeje i Herkulanum, (tłum. H. Rowińska), PIW, Warszawa.

Górski W. (1882), Piramidy w Gizeh, „Tygodnik Ilustrowany”, t. XIV, nr 359, s. 306.

Hordyński W. (1959-1960), Górski Władysław, [w:] Polski Słownik Biograficzny, t. VIII, Kraków, s. 456.

H. N. (1867), Najnowsze odkrycia, wynalazki i spostrzeżenia naukowe, „Tygodnik Ilustrowany", t. XVI, nr 406, s. 6-8.

Kaczmarek R. (2008), Polacy w Egipcie do 1914 roku, Wydawnictwo Naukowe Uniwersytetu Szczecińskiego, Szczecin.

Kaszewski K. (1868), O sztuce starożytnej Grecyi. Z powodu dzieła Józefa Kremera: „, Grecyja starożytna i jej sztuka a zwłaszcza rzeźba”, „Tygodnik Ilustrowany”, t. II, nr 50, s. 284-285; nr 51, s. 292-294.

Kraszewski J. I. (1872), Kronika zagraniczna, „Tygodnik Ilustrowany”, t. X, nr 253, s. 218.

Kraszewski J. I. (1875), Kronika zagraniczna, „Tygodnik Ilustrowany”, t. XVI, nr 413, s. 344 .

Kremer J. (1866), O sztuce Grecyi starożytnej, „Tygodnik Ilustrowany”, t. XII, nr 342, s. 167-169; nr 344, s. 194-196. 
Kronika...1901, Kronika Powszechna. Odkrycia archeologiczne, „Tygodnik Ilustrowany", nr 23, s. 864.

Kronika...1902a, Kronika Powszechna. Archeologia, „Tygodnik Ilustrowany”, nr 21, s. 479.

Kronika...1902b, Kronika Powszechna. Archeologia, „Tygodnik Ilustrowany”, nr 47, s. 940.

Kronika...1902c, Kronika Powszechna. Wskrzeszenie Thaidy, „Tygodnik Ilustrowany”, nr 5, s. 97.

Kronika...1903, Kronika Powszechna. Archeologia, „Tygodnik Ilustrowany”, nr 48, s. 958.

Lipska J. (2003), W cieniu piramid, Ossolineum, Wrocław.

Michałowski K. (1970), Jak Grecy tworzyli sztukę, Wiedza Powszechna, Warszawa.

Najnowsze... (1898), Najnowsze odkrycia $w$ dziedzinie sztuki i archeologii, „Tygodnik Ilustrowany", nr 21, s. 414-415.

Niwiński A. (2003), Czekajac na Herhora... Odkrywanie tajemnic Teb Stubramnych czyli szkice z dziejów archeologii Egiptu, Świat Książki, Warszawa.

Ormian-Michta E. (2004-2005), Stecki Tadeusz Jerzy, [w:] Polski Słownik Biograficzny, t. XLIII, Kraków, s. 95-96.

Pawiński A. (1880), Arcydzieła plastyki greckiej świeżo odkryte w Małej Azji, w dawnem mieście Pergamie, ,Tygodnik Ilustrowany”, t. IX, nr 233, s. 371-373; nr 234, s. 386; nr 235, s. 410-412.

Pawiński A. (1885), Ogród Olimpijski zpod zwalisk osłonięty, „Tygodnik Ilustrowany”, t. VI, nr 137, s. 101-102; nr 138, s. 117-118; nr 39, s. 144.

Pawiński A. (1891), Ekshumacya miasta, „Tygodnik Ilustrowany”: nr 136, s. 89-91, 96, nr 137, s. 108-111.

Press L. (1996), Henryk Schliemann w oczach polskich pisarzy $i$ publicystów w XIX wieku, ,Meander”, nr 9-10, s. 519-532.

Przed... (1909), Przed czterema tysiqcami lat, „Tygodnik Ilustrowany”, nr 16, s. 321.

Rekowska M. (1995), Malownicza podróż. Polaków spostrzeżenia o antyku pótnocnej Italii, ,Meander”, nr 1-2, s. 75-79.

Rozmaitości... (1883), Rozmaitości z literatury, sztuki $i$ życia społecznego, „Tygodnik Ilustrowany", t. I, nr 16, s. 255-256.

Schliemann Henryk (1891), „,Tygodnik Ilustrowany”, t. III, nr 54, s. 12.

Stecki T. J. (1871), Korespondencja Tygodnika Ilustrowanego. Florencja, „Tygodnik Ilustrowany", t. VII, nr 158, s. 8-9.

Tarquinia, [w:] Encyklopedia sztuki starożytnej. Europa - Azja - Afryka - Ameryka, red. A. Derwojedowa, A. Dulewicz, B. Grochala, PWN, Warszawa 1998, s. $258-259$.

Toporczyk (1883a), Ze świata obcego, „Tygodnik Ilustrowany”, t. I, nr 21, s. 331. 
Toporczyk (1883b), Ze świata obcego, „Tygodnik Ilustrowany”, t. II, nr 31, s. 67-68.

Toporczyk (1886a), Ze świata obcego, „Tygodnik Ilustrowany”, t. VII, nr 162, s. $90-91$.

Toporczyk (1886b), Ze świata obcego, „Tygodnik Ilustrowany”, t. VIII, nr 196, s. 212-213.

Tyldesley J. (2002), Ramzes Wielki, (thum. E. Witecka), Wydawnictwo Alfa, Warszawa.

Tyldesley J. (2005), Egipt. Jak zaginiona cywilizacja została na nowo odkryta, (tłum. D. Niedziółka), Prószyński i S-ka, Warszawa.

Tyszkiewicz M. (1865), Pobyt w Kairze, „Tygodnik Ilustrowany”, t. XI, nr 287, s. $110-113$.

Unger J. (1859), Prospekt „, Tygodnika Ilustrowanego”, Warszawa.

Vogüé de E. (1878), W krainie faraonów, „Tygodnik Ilustrowany”, t. V, nr 115, s. 159; nr 116, s. 170-175; nr 117, s. 190-192; nr 118, s. 206-208.

Vogüé..., Vogüé Eugène Melchior, [w:] Encyklopaedia Britannica, New York 2011, v. XXVIII, s. 172.

W. Ch. (1877), Kronika paryzka, ,Tygodnik Ilustrowany”, t. III, nr 77, s. 373-374.

W[incenty] K[orotyński] (1886), Ramzes II, „Tygodnik Ilustrowany”, t. VIII, nr 196, s. 213-214.

Węclewski Z. (1870), O sztuce greckiej i chrześcijańskiej. Dwa odczyty, „Tygodnik Ilustrowany", t. V, nr 119, s. 179-180; nr 120, s. 188-190; nr 122, s. 213-215; nr 123, s. 224-226.

Wielowiejski H. (1871), Z podróży po Włoszech, „Tygodnik Ilustrowany”, t. VII, nr 160, s. $28-30$.

Strony internetowe

Brugsch H. (tłum. G. Laughead, P. Sarah), My life and my travels, http://www.vlib.us/ brugsch/chapter3.html (dostęp: 1.09.2011).

Giuseppe Fiorelli, http:/www.britannica.com/EBchecked/topic/207698/GiuseppeFiorelli (dostęp: 18.08.2011).

Krawczyk M., Miasta Wezuwiusza w tygodnikach warszawskich, http://www.archeolog. pl/pl33/teksty43/miasta_wezuwiusza_w_tygodnikach_warszawskich(dostęp: 12.07.2011).

http://www.archeorm.arti.beniculturali.it/ada/storia/archeologi/rosa.htm (dostęp: 12.07.2011). 


\section{Summary}

\section{FOREIGN ANTIQUITIES IN „TYGODNIK ILUSTROWANY” TO 1914}

„Tygodnik Ilustrowany” was one of the most important magazines in Warsaw in the $2^{\text {nd }}$ half of nineteenth century. From the first issues of the magazine there is information about the national Antiquities. The reports of foreign Antiquities began to appear in the $2^{\text {nd }}$ half of 1860 s, and since then their number is steadily increasing. Most texts describing the discovery and ancient monuments were in the 1880s. Individual articles have appeared in the $1890 \mathrm{~s}$. At the beginning of the twentieth century once again increased the number of texts about Antiquities.

Archaeological issues are not just confined to the news about the excavations. In „Tygodnik” placed biographies of scholars and collectors. Informed about exhibitions and museums that collect artifacts from the ancient times. Has also been reported same artifacts. There were also reprints articles in foreign languages. They were in the section „Artykuły treści naukowej, z innych piśmiennictw czerpane”. Small foreign reports of findings were published in „Ze świata obcego” edited by Mścisława Edgara Trepkę (Toporczyka), and later in the „Kronika Powszechna”. At this time the authors of the articles represented a variety of disciplines. 